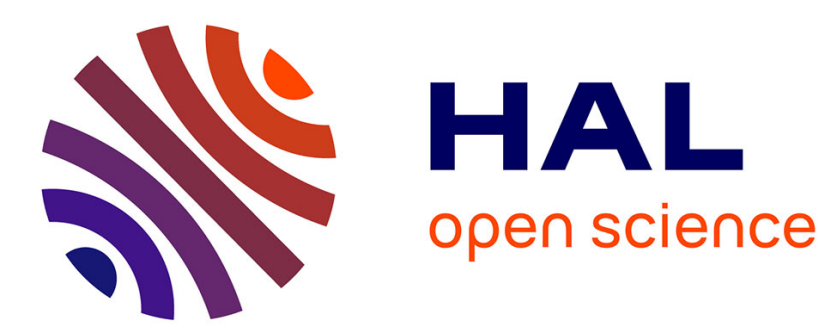

\title{
Who Becomes a Terrorist Today?
}

Scott Atran

\section{To cite this version:}

Scott Atran. Who Becomes a Terrorist Today?. Perspectives on Terrorism, 2008, 2 (5), pp.000. ijn_00505183

\section{HAL Id: ijn_00505183 \\ https://hal.science/ijn_00505183}

Submitted on 22 Jul 2010

HAL is a multi-disciplinary open access archive for the deposit and dissemination of scientific research documents, whether they are published or not. The documents may come from teaching and research institutions in France or abroad, or from public or private research centers.
L'archive ouverte pluridisciplinaire HAL, est destinée au dépôt et à la diffusion de documents scientifiques de niveau recherche, publiés ou non, émanant des établissements d'enseignement et de recherche français ou étrangers, des laboratoires publics ou privés. 
- About

- Journal Archives

- Article Forum

search...

\section{Perspectives on Terrorism}

- Home

- Journal Archives

○ Print Edition

- About

- Contact

Home Journal Archives

- Back to Perspectives on Terrorism Past Issues

- Back to Perspectives on Terrorism This Issue

Volume II, Issue 5

\section{Perspectives on Terrorism -}

\section{Who Becomes a Terrorist Today?}

By Scott Atran

\section{Introduction: Takfiri Terrorism}

Since the invasion of Iraq, and with the rapid spread of Internet access, the world has witnessed a more egalitarian, less-educated and -materially well off, and more socially marginalized wave of would-be jihadi martyrs. Although millions of people support violent jihad, very few are willing to do it. Those who do pursue violent jihad usually emerge in small groups of action-oriented friends. They come from the same neighborhood and interact during activities, such as soccer or paintball. Often they become camping and hiking companions who learn to take care of one another under trying conditions, which causes them to become even more deeply attached. Increasingly, they may first meet in a chat room where the anonymity of the World Wide Web paradoxically helps to forge intimate emotional ties among people who might otherwise physically intimidate or put off one another. They learn to live in a parallel universe - a conceptually closed community of 
comrades bound to a cause - which they mistake for the world.

These young people self-mobilize to the tune of a simple, superficial, yet broadly appealing "takfiri" message of withdrawal from impure mainstream society and the need for violent action to cleanse it. It is a surprisingly flat but fluid message pre-adapted to any new event in the world, which is readily shared by young people I have interviewed from the remote Indonesian Island of Sulawesi, to the Spanish enclave of Ceuta (Septa) in North Africa, and in places scattered throughout Pakistan, Palestine, and the suburbs of Paris.

Takfiris (from takfir, "excommunication") are rejectionists who disdain other forms of Islam, including wahabism (an evangelical creed which preaches Calvinist-like obedience to the state) and most fundamentalist, or salafi, creeds (which oppose fighting between co-religionists as sowing discord, or fitna, in the Muslim community). Salafi Islam is the host on which this viral Takfiri movement rides, much as Christian fundamentalism is the host upon which White Supremacism rides. The host itself is not the cause of the virus and is, indeed, a primary victim. As one senior Saudi intelligence officer recently told me, "Often the first sign of someone becoming a Takfiri is that he stops praying where his family and tribe pray. He leaves the mosque and turns against his family, tribe and our Salafi way."

One telltale sign of radicalization in the move to Takfirism is when members of a neighborhood mosque or cultural center (or just an informal discussion group that meets at a bookstore or at picnics) gel into a militant faction that leaves, voluntarily or involuntarily. This is what happened, for example, when Ali al-Timimi and his group of paintball buddies were ejected from the Dar al-Arqam Cultural Center in Falls Church, Virginia, after praising the 9/11 attack (12 members of the group were later convicted for aiding Lashkar-e-Taiba, a Pakistani group allied to alQaeda). Another example is when the soccer-playing Salafi Imam at the M-30 mosque in Madrid expelled Serhane Fakhet and friends (who continued to self-radicalize, playing soccer and picnicking together, in the lead up to the Madrid train bombings).

Western politicians, pundits, and publics generally do not understand that the strict Salafi schools in Indonesia, Egypt, Saudi Arabia, Yemen and elsewhere are the most vociferous and effective opponents of violent jihad. Most present-day Takfiris are "born again" in their late teens and 
early twenties and have little knowledge of religion beyond the fact that they consider themselves "true Muslims" who must fight enemies near and far to defend their friends and the faith that makes their friendship meaningful and enduring.

Soccer, paintball, camping, hiking, rafting, body building, martial arts training and other forms of physically stimulating and intimate group action create a bunch of buddies (usually not less than 4 and not more than 12, with a median of 8), who become a "band of brothers" in a glorious cause. It usually suffices that a few (usually at least two) of these action buddies come to believe in the cause, truly and uncompromisingly, for the rest to follow even unto death. Humans, like all primates, need to socially organize, lead and be led; however, notions of "charismatic leaders" going out or sending recruiters to "brainwash" unwitting minds into joining well-structured organizations with command and control is grossly exaggerated. Standard counterterrorism notions of "cells" and "recruitment" - and to some degree even "leadership" - often reflect more the psychology and organization of people analyzing terrorist groups than terrorist groups themselves.

Such "bureaucratic mirroring" is also evident in misguided policies grounded in the premise that simply presenting people with rational arguments and material incentives will lead them down the correct or better path. Most human beings are more interested in persuading themselves that they are right, whatever the evidence against them, than in finding out that they are wrong. They are more interested in victory than truth. And when was the last time rational argument or a buy-off offer convinced anyone you know to select the right (boy or girl) friend?

\section{Problems with Prevailing Theories of Terrorism: Outdated Data and Inattention to Detail}

Alan Krueger, in his new book What Makes a Terrorist: Economics and the Roots of Terrorism (Princeton University Press, 2007), produces data for three general findings: (1) poverty and lack of education are uncorrelated, or slightly negatively correlated, with being a terrorist or support for terrorism; (2) most terrorists stem from countries that are not poor, but that restrict civil liberties; and (3) terrorism is mostly directed against democratic rather than authoritarian regimes. He then infers causes from these broad correlations: (A) poverty and poor education do not produce terrorism, but denial of political freedom does; and (B) terrorists target democratic regimes because terrorists seek 
publicity and widespread panic and democracies are more responsive to public opinion. These conclusions echo Robert Pape's best-selling book Dying to Win: The Strategic Logic of Suicide Terrorism (University of Chicago Press, 2005).

A major problem with such works is that they assume correlations with economic status, education level, or degree of civil liberties usefully predict who or how people become terrorists. This mistaken premise misleads policymakers and researchers. It is the social networks and group dynamics of these networks that are critical to understanding how terrorist networks form and operate, not the demographic profiles of individuals and whole populations.

Consider Islamic terrorism, the main focus of Krueger's book. The significant correlation between the countries of origin of Islamic terrorists and countries that limit civil liberties is true, but uninformative. The same correlation holds for indefinitely many Muslim groups that have nothing to do with terrorism.

Only al-Qaeda is interested in attacking the "far enemy," that is, the United States and its allies. Isaac Ben Israel, an Israeli parliamentarian who currently heads his country's space agency, was former chief of air force operations and top military strategist in a successful campaign to stop Hamas suicide bombings. He told me that "al-Qaeda is a very different problem and is not ours; our operational problems with Hezbollah and Hamas involve regional networks with regional aims, although we are ready to help the United States with its global al-Qaeda problem whenever we can." More than 80 percent of people who have joined or expressed allegiance to al-Qaeda have done so outside their country of origin. This, of course, is not the case with Hezbollah or Hamas. Whether one joins jihad in the diaspora or in one's native country, and not country of origin per se, is the key factor in how one is willing to use terrorism and against whom.

The correlation between terrorist acts and target countries, indicating that democracies are victims more than autocracies, is spurious. It requires accepting that attacks on U.S occupation forces in Iraq and Afghanistan are attacks upon U.S. democracy. In fact, there have been very few attacks carried out directly against western democracies, and only three with significant casualties (USA-11 September 2001, Spain-11 March 2004, UK-7 July 2005). There have been no major attacks against the democracies of Israel or Indonesia in the last two years, and only one major attack in India outside the disputed territory of Jammu-Kashmir 
(11/07/06 in Mumbai). There have been 2400 arrests related to Takfiri terrorist activities in Europe, where civil liberties are guaranteed.

Only in Iraq and Afghanistan has there been a continuing high rate of attacks against US-led coalition forces, which are increasingly perceived as occupation forces by large segments of the populations of these two countries. It is doubtful that reaction would be much different if invasion and occupation forces were those of a dictatorship, as with Soviet forces in Afghanistan in the 1980s. The world's newest and most active areas for suicide attacks are Pakistan and North Africa, where civil liberties are restricted. Over 200 people were killed in North Africa in 2007, mostly in Algeria. In Pakistan, nearly 500 were killed in suicide attacks in the second half of 2007 (including former Prime Minister Benazir Bhutto), greater than the number of people killed in terrorist attacks in Europe over the last two decades. Local groups proclaiming allegiance or sympathy with al-Qaeda have claimed responsibility, but al-Qaeda does not appear to have direct operational command or control over any of these groups.

Consider, now, the relationship between socioeconomic status and terrorism. To independently confirm Krueger's findings on Hamas my research group statistically regressed Palestinian support for suicide attacks against Israelis on education and income levels in three nationally representative surveys of Palestinians (West Bank and Gaza) from 1999, 2001 and 2005. We controlled for area of residence, refugee status, age, gender and religion. Income and education levels were unrelated to support for suicide attacks. When there was a relationship between support for suicide attacks and economic variables we found, like Krueger, that income and education levels are modestly, but positively correlated with support. In the 1999 survey, wealthier Palestinians expressed greater support for attacks, while more educated Palestinians showed greater support for suicide attacks in the 2001 surveys.

But when we turn to al-Qaeda's most important Southeast Asian ally Jemaah Islamiyah (JI), we find something different. We analyzed every attack by Southeast Asia's JI between 1999 and the second Bali bombing of 2005 (apart from the purely local conflicts of Poso and Ambon) and entered demographic details on all known operatives. Of about 180 people implicated in JI attacks, 78 percent worked in unskilled jobs, and only 23 percent had education beyond high school. 
We also found that operational associations in JI are determined by four variables: (1) being a member of the self-styled "Afghan Alumni," that is, someone who went through training with the Indonesia volunteers in the Abu Sayyaf's Sadah training camp during the Soviet-Afghan War and its immediate aftermath; (2) continuing to work together (e.g., on Abdullah Sungkar's chicken farm in Malaysia) or to play soccer together after demobilization from Afghanistan (and before JI was officially established); (3) having studied or taught in at least one of the two religious schools established by JI's founders (Al-Mukmin in Java and Lukman Al-Hakiem in Malaysia); and (4) being related by kinship or marriage to someone else in the network (e.g., there are more than 30 marriages woven through 10 attacks). In contrast with these factors, we find that the knowledge of JI's "official" organizational structure is largely uninformative in helping us to understand the networks involved in JI attacks.

Levels of education and skill are significantly higher for Hamas than for JI. Nevertheless, the main predictors for involvement in suicide attacks are, again, small-world aspects of social networks and local group dynamics rather than large-scale social, economic, and political indicators, such as education level and economic status. For example, Hamas' most-sustained suicide bombing campaign in 20032004 involved several buddies from Hebron's Masjad (mosque) al-Jihad soccer team. Most lived in the Wad Abu Katila neighborhood and belonged to the al-Qawasmeh hamula (clan); several were classmates in the neighborhood's local branch of the Palestinian Polytechnic College. Their ages ranged from 18 to 22 years old. At least eight team members were dispatched to suicide shooting and bombing operations by the Hamas military leader in Hebron, Abdullah al-Qawasmeh (killed by Israeli forces in June 2003 and succeeded by his relatives Basel alQawasmeh, killed in September 2003, and Imad alQawasmeh, captured on October 13, 2004). A closer look at actual attacks reveals that almost all are rooted in local networks of pre-existing social relationships.

In February 2008, I interviewed members of the families of suicide bombers Mohammed Herbawi and Shadi Zghayer, shortly after an attack in Dimona, Israel. This was the first suicide attack claimed by Hamas since December 2004, when Hamas declared a unilateral truce on martyrdom actions across the Green Line. These two friends were members of the same Hamas neighborhood soccer group as several others who died in 2003: the Masjad al-Jihad team. Herbawi had been arrested as a 17-year-old on March 15, 
2003, shortly after a suicide bombing on Haifa bus (by Mamoud al-Qawasmeh on March 5, 2003) and coordinated suicide shooting attacks on Israeli settlements by others on the team (March 7, 2003, Muhsein, Hazem al-Qawasmeh, Fadi Fahuri, Sufian Hariz) and before another set of suicide bombings by team members in Hebron and Jerusalem on May 17-18, 2003 (Fuad al-Qawasmeh, Basem Takruri, Mujahed al-Ja'abri). Herbawi's mother, Basma Harmoni (she is divorced), said her son loved all those boys.

The Imam at Masjad al-Jihad, Fellah Naser Ed-Din, is also crazy about soccer (he showed me albums of his soccer team pictures since his boyhood days) and refereed the boys. The Imam told us that the soccer buddies selforganized matches involving 15 mosque teams in the area, naming the matches after martyrs (a painted sign behind the goalpost at the Abu al-Dhabat school reads "Championship by Martyr Ra'ed Missak," in honor of the young man from Hebron who killed 23 people and wounded more than 130 on a Jerusalem bus on August 19, 2003). According to the Imam, Muhsein Qawasmeh was the smartest and best of the 2003 team and he inspired the others. I received much the same message from Fawzi Qawasmeh, father of one of the young men, who went on the mission with Muhsein. Hazem Qawasmeh, who went on the mission with Muhsein, stated that "without Muhsein, I doubt the other would have would have acted." At the house where Muhsein's family now lives, I found his mother and brother commiserating with Herbawi's uncle. Muhsein's mother said her son had been an exemplary student but left school after the Intifada broke out and focused on soccer and religion.

The Hamas leadership in Damascus later claimed responsibility for the Dimona attack (after Fatah's Al-Aqsa' Martyrs Brigades had claimed it) but the politburo clearly did not order it or even know about it (Usama Hamdan, who handles external relations for Hamas in Beirut, initially said he didn't know who was responsible; and when I asked senior Hamas leaders in the West Bank if this meant that he didn't know about it they said, "You can conclude that; we certainly didn't"). Sources close to Israeli intelligence told me at the Knesset that Mahmoud Zahar, the Hamas leader in Gaza, and Ahmed Al Ja'abri, the military commander of the Izz ad-Din al-Qassam Brigades, probably wanted to launch an operation across the Israel-Egypt border after Hamas breached the border wall between Gaza and Egypt but couldn't, so al-Ja'abri called upon his clan ally in Hebron, Ayoub Qawasmeh, to do an operation. Ayoub Qawasmeh then tapped into the young men on the soccer team who had been earnestly waiting to do something for

ShareThis

Subscribe to our Newsletter! 
their comrades and their cause.

The most complete data in Krueger's book concerns Hezbollah and Hamas. There is a secondary focus on alQaeda. For all three cases, the data is old and of questionable relevance to global terrorism today. Hezbollah ceased suicide bombings and attacks on civilians (outside of open war) by the 1990s. Hamas has claimed responsibility for only one attack since December 2004. al-Qaeda central, the command set up by Osama Bin Laden in the summer of 1988 and which was involved in the 9/11 attacks, has had no direct success in carrying out a terrorist operation since 2002 (the Djerba, Tunisia bombings), though it had a hand in prior financing of operations carried out later (Istanbul bombings 2003) and in training people implicated in subsequent attacks (about 50 suicide bombers involved in attacks in Saudi Arabia through April 2005).

The original al-Qaeda group around Bin Laden (mostly Egyptians) has been decimated by about an order of magnitude. Al-Qaeda's surviving remnants are mostly concentrated in a handful of small mobile camps in Pakistan's Federally Administered Tribal Areas. The largest remaining al-Qaeda camp in 2007, Mir Ali in North Waziristan, has had a few dozen trainees under the tutelage of Abu Ubaydah Al-Masri. Al-Masri instructed those responsible for the summer 2006 suicide bombing plot to smuggle liquid explosives aboard a number of passenger jets, and he has likely been involved in a few other dangerous but so-far unsuccessful plots.

For the most part, the "new wave" of terrorism that expresses allegiance to al-Qaeda tends to be poorer, less educated and more marginal than the old al-Qaeda or its remnants. It relies to a greater extent for financing and personnel on pre-existing petty criminal networks because large-scale financing is easily tracked (the attacks on Sept. 11 cost some $\$ 400,000$ followed by the 2002 Bali and 2004 Keywords bombings at about $\$ 50,000$ each, with all others considerably less). The Saudi Ministry of Interior conducted a study of 639 detainees through 2004 and is presently finishing a newer study through 2007. Nearly two-thirds of those in the sample say they joined Jihad through friends and about a quarter through family. A closer look at other terrorist groups reveals strikingly similar patterns of selfradicalization based on almost chance encounters within research review school science security social state pre-existing local circles of friends and kin. Former CIA case officer Marc Sageman analyzed Qaeda networks strategic studies study support terrorism through 2003 and found that about 70 percent join through terrorist terrorists understanding violence world friends and 20 percent through kin. In his new book years
- Interview with Ramadan Shallah, Secretary General, Palestinian Islamic Jihad

- The Impact of Terrorism on Democracy in Northern Ireland

- Irish Republicanism and the Internet: support for New Wave Dissidents

- Through the Lenses of Hollywood: depictions of Terrorism in American Movies

- Officially Blacklisted Extremist/Terrorist (Support) Organizations: a Comparison of Lists from six Countries and two International Organizations

- Book Review: Mark Perry. How to Lose the War on Terror

- Book Review: Anneli Botha. Terrorism in the Maghreb: The Transnationalisation of Domestic Terrorism

- Selected Literature on Radicalization and De-radicalization from Terrorism

- Conference Calendar (March - May 2010)

- Democracy and Terrorism

\section{PT News}

- Greetings and Welcome to Perspectives on Terrorism

- TRI Openings

analysis $\underline{\text { article assistant associate attacks center }}$ $\underline{\text { centre counter }} \underline{\text { countries }}$ currently editor global groups institute international military muslim national pakistan perspectives political professor qaeda 
Leaderless Jihad: Terror Networks in the $21^{\text {st }}$ CenturyCreated with Zaragoza Clouds (University of Pennsylvania Press, 2007) Sageman finds that more recent networks are also built up around friendship and

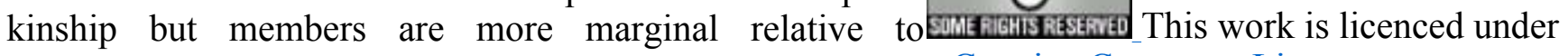
surrounding society. a Creative Commons Licence.

The newer Saudi sample bears this out. Compared with thejSearch earlier sample, the newer wave tends to be somewhat younger (and more likely to be single), less educated and less financially well off, less ideological, and more prone to prior involvement in criminal activities unrelated to Jihad, such as drugs, theft, and aggravated assault. They are much more likely to read jihadi literature in their daily lives than other forms of literature. They tend to look up to role models who stress violence in Jihad, like the late Abu Musab alZarqawi, than to those who justify and limit violence through moral reasoning, such as the late Abdullah Azzam. A majority come to religion later in life, especially in their early twenties. In the older cohort there was little traditional religious education; however, the newer cohort tends to be less ideologically sophisticated and especially motivated by desire to avenge perceived injustices in Iraq. (When I asked detainees in Saudi Arabia who had volunteered for Iraq why they had, some mentioned stories of women raped, the killing of innocents and desecrations of the Koran, but all mentioned Abu Ghraib).

This "new wave" pattern of increasingly marginality and "born-again" religion is reflected in European and North African groups that express allegiance to al-Qaeda, as well as foreign fighters in Iraq (41 percent from Saudi Arabia and 39 percent from North Africa since August 2006, many of whom come in bunches from the same town, for example, the 50 or so volunteers from Darnah, Lybia, according to West Point's Sinjar Report on Foreign Fighters in Iraq).

Krueger and others repeatedly refer to predictive factors in "recruitment." It is important to understand that there is no, and has never been, clear evidence of "recruitment" into alQaeda. In its heyday, al-Qaeda operated more like a funding agency than a military organization. People would come to al-Qaeda with proposals for plots. Al-Qaeda would accept some 10-20 percent. Even the 9/11 suicide pilots were not "recruited" into Al-Qaeda. They were Middle Eastern Arabs who lived in a middle-class Germany community (the Hamburg suburb of Harburg) and were seeking friendship and identity in an Islamic community that was mostly Moroccan. Our interviews with friends in their circle and investigators reveal that the plotters met in the dorms and started hanging out together, including going to mosque 
services and meeting in local restaurants. Three wound up living in the same apartment, where they self-radicalized. They first thought of going to Chechnya to do jihad (but getting there proved too difficult) then to Kosovo (but the Albanian jihadis didn't want them), and eventually wound up in an al-Qaeda training camp in Afghanistan as a distant third choice.

There is no clear evidence that al-Qaeda ever had a recruiting or training infrastructure in Europe, although there is increasing evidence that al-Qaeda and al-Qaedarelated groups in Pakistan's tribal areas maintain communication with Europeans after the train in Pakistan. This seems to be especially the case with those involved in recent plots in the United Kingdom. Generally, however, people go looking for al-Qaeda, not the other way around. Because there is very little of the old al-Qaeda left, many who go seeking al-Qaeda are caught. Those who seek out al-Qaeda do so in small groups of friends, and occasionally through kin. Almost all are schoolmates or workmates, and camp, soccer, or paintball buddies. Only a minority has gone beyond high school. Some have steady jobs and family, but many have only intermittent jobs and no families of their own. All have self-radicalized to some degree as friends before they go after al-Qaeda, although an encounter with someone who has been to an al-Qaeda training in camp in Afghanistan is occasionally an added stimulant. The overwhelming majority have not had sustained prior religious education but become "born again" into radical Islam in their late teens and early 20s. About 10 percent are Christian converts.

For example, in the wake of the Iraq invasion in April 2003, a disciple of the radical Islamist preacher Sheikh Omar Bakri organized a barbecue in a London suburb for about 100 people, most from the immigrant Pakistani community. Guests were asked for donations to help send a few volunteers to Pakistan to train for Jihad. Among those who used some of 3,500 euros collected to pay their way to Pakistan were Mohammed Sidique Kahn, one of the four suicide bombers in the July 2005 London Underground attack, and Omar Khyam, one of the conspirators convicted in the 2005 "Crevice" plot to plant fertilizer bombs around London. Their original intention was to do Jihad in Kashmir, but after a quick course in bomb-making they were told to "go home" and do something there. Each joined up with a few friends to concoct a plot. Interviews by journalist Jason Burke with investigators and friends familiar with the Crevice case suggest that 10 days of arduous hiking, camping, and training in Pakistan cemented 
commitment between buddies who learned to live together and care for one another. White-water rafting seems to have played a similar role in bonding the London Underground plotters. One of the four London suicide bombers was also a Jamaican Christian convert and pinball buddy.

Another telling example is the Madrid train bombing in March 2004. Five of the seven plotters who blew themselves when cornered by police grew up within a few blocks of one another in the tumble-down neighborhood of Jemaa Mezuak in Tetuan, Morocco: Jamal Ahmidan ("El Chino"), brothers Mohammed and Rachid Oulad Akcha, Abdennabi Kounjaa ("El Afghan"), and Rifaat Asrin ("El Niño). One, nicknamed the "Chinaman," fled Morocco in 1993 from a murder charge, joining his elder brother in Madrid in taking and dealing drugs. In 1995, with his teenage Christian girlfriend and fellow junkie five months pregnant, the Chinaman decided to kick his heroin habit. His wife says he did it cold turkey with the help of the religion he was getting in a local mosque. The Chinaman turned around to preach reform to his drug-dealing associates, three brothers from the Mezuak, convincing two to quit their habit. The brothers became devoted to the Chinaman, and thereafter known in the barrio as his "bodyguards."

The fourth of Madrid's Moroccan suicide bombers was described to us by some of his friends as Mezuak's first "Afghan" (a religious militant who grows a full beard and dresses with an Afghan hat, coarse knee-length tunic and sandals). He would preach jihad against "infidels" (kuffar) and Muslims who merit "excommunication" (takfir) because they refuse to follow "pure" Islamic ways. The father and friends of the fifth suicide bomber, a young gay man in his early 20s known as "The Kid," said that he had sold candies from a cart in Mezuak until 2000. He did not care much for religion until he was hooked up with The Afghan. By 2002, The Afghan and The Kid were in Madrid, the former as a part-time construction worker who dealt drugs with the Chinaman's "bodyguards," and the latter devoting himself to charity work helping out other young immigrants.

In the fall of 2003, just after the Chinaman returned from a prison stint in Morocco, he and his chums from the "old neighborhood" of Mezuak linked up with the economicsturned-religious student Serhane Fakhet and his buddies at a couple of apartment-mosques and soccer fields, and in daily dealings along Tribulete Street (at the halal butcher shop, the Alhambra restaurant, the barbershop, and the cell phone 
and Internet store) in the Lavapies neighborhood of central Madrid. The hands-on drug dealer and dreamy student bonded in an explosive combination. There was no alQaeda, or any other outside organization, involved.

From March to December 2007, I went to the Mezuak, and found that at least a dozen other young men had "gone Afghan" since the summer of 2006, according to local residents who knew them. Each would one day suddenly shave his beard, don western clothes and simply disappear; sometimes two vanished on the same day. Their friends and local Moroccan police say that they probably left for Iraq to become martyrs. The names and itineraries of 5 of them have been confirmed: Abdelmonim al-Amrani, Younes Achebak, Hamza Aklifa, and the brothers Bilal and Muncef Ben Aboud (DNA analysis has confirmed the suicide bombing death of Amrani in Baqubah, Iraq). All 5 attended a local elementary school (Abdelkrim Khattabi), the same one that Madrid's Moroccan bombers attended. And 4 of the 5 were in the same high school class (Kadi Ayadi, just outside Mezuak). The fifth, Bilal's brother Muncef, was a gifted mathematics student who went on to receive a scholarship to Morocco's prestigious air force academy, the École Royale de l'Air. But Muncef's mother said he was unsettled by what was happening around the world to Muslims and left his studies as he sought solace in religion.

All were soccer buddies who prayed at Masjad al-Rohban (the Dawa Tabligh mosque where Kounjaa had first gone "Afghan") and all hung out at the Chicago Café on Mamoun Street, Mezuak's main drag. The cousin of one of the Iraq-bound group (Hamza) was married to The Afghan, and all prayed in the same mosque where The Afghan first preached Jihad (the mosque's Imam was arrested in 2006 for collecting zaqat charity money from local business men to help send young men to Iraq). Friends say the young men bound for Iraq all respected the courage of the Madrid plotters but disagreed about their civilian targets and believed that action in Iraq would be more just and "soldierly" than in Europe. Like the Madrid plotters (as well as the Hamburg and London plotters), they were buddies, hung out together at local cafés and restaurants, and mingled in the same barbershops (where young men gather and talk).

The boundaries of the newer-wave networks are very loose, and the Internet now allows anyone who wishes to become a terrorist to become one anywhere, anytime. For example, the "Al-Ansar" chat room network was involved in plots by young men in half-a-dozen countries (U.S., U.K., Canada, 
Sweden, Denmark, Bosnia), and many of the men had never physically met. They would hack into Midwest media sites to post jihadi videos (e.g., of Zarqawi's beheading of Nick Berg) and recipes for making car bombs and suicide vests from scratch. From a basement apartment in Britain, a selfstyled Irhabi 007 ("Terrorist 007") helped in his spare time to coordinate plots with some high school chums in Toronto to blow up the Canadian parliament, and with others to attack the U.S. embassy in Bosnia (3 conspirators who did meet up physically in Bosnia were arrested with AK-47s, suicide belts, and thousands of rounds of ammunition).

A main problem in terrorism studies is that most "experts" have little field experience (for understandable but not insurmountable reasons) and otherwise lack the required level of details that statistical and trend analyses could properly mine. There are many millions of people who express sympathy with al-Qaeda or other forms of violent political expression that support terrorism. From a 20052006 survey of 10 countries involving 50,000 interviews, a Gallup study projected that 7 percent of the world's 1.3 billion Muslims (some 90 million people) felt that the attacks on Sept. 11 were "completely justified." There are, however, only a few thousands who show willingness to actually commit violence. They almost invariably go on to violence in small groups consisting mostly of friends and some kin (although friends tend to become kin as they marry one another's sisters and cousins; indeed, there are dozens of such marriages among members of Southeast Asia's Jemaah Islamiyah).

\section{Conclusions from the Field}

The causes that humans are most willing to kill and die for are not just about particular ideas; they are about particular groups of people, in particular places, at particular times. Terrorist groups that kill and die for the Takfiri cause arise within specific "scenes": neighborhoods, schools (classes, dorms), workplaces, common leisure activities (soccer, mosque, barbershop café) and, increasingly, online chat rooms. The process of self-selection into terrorism occurs within these scenes. Takfiri terrorism is stimulated by a massive, media-driven transnational political awakening in which Jihad is represented as the only the way to permanently resolve glaring problems of global injustice. This incites moral outrage against perceived attacks upon Islam. If moral outrage resonates with personal experience that reverberates among friends in a scene, and if aspects of the scene are already sufficiently action-oriented, such as group of soccer buddies or camp mates, then willingness to 
go out and do violence together is much more likely.

The publicity associated with spectacular acts of violence in the name of justice is the oxygen that currently fires terrorism. As Saudi Arabia's General Khaled Alhumaidan crisply said to me recently in Riyadh, "The front is in our neighborhoods but the battle is the silver screen. If it doesn't make it to the six o'clock news, then al-Qaeda is not interested." These young people constantly see and discuss among themselves images of war and injustice against "our people," become morally outraged (especially if injustice resonates personally, more a problem with immigrants in Europe than the USA), and dream a war for justice that gives their friendship cause. They mostly self-radicalize in cafés, barbershops, restaurants, and informal discussion groups (people mostly pray in mosques, not plot in them).

Most human violence is committed by young people seeking adventure, dreams of glory, and esteem in the eyes of their peers. Omar Nasiri's Inside Jihad: My Life with Al Qaeda (Perseus Books, 2006) rings true in its picture of the highs the militants get from the sense of brotherhood and sense of purpose. They want to belong to something that is at once intimate, bigger, and more permanent than a person alone. They kill and die for faith and friendship, which is the foundation of all social and political union, that is, all enduring human associations of non-kin: shared faith reigns in self-interest and makes social life possible; friendship allows genetically unrelated individuals to cooperate to compete. The most heroic cause in the world today is Jihad, where anyone from anywhere can hope to make a mark against the most powerful army in the history of the world. But they need their friends to give them courage, and it is as much or more for love of comrades than the cause that they will kill and die for in the end.

This new wave of Takfirism is about youth culture, not theology or ideology. It is mostly irrelevant to classic military and law enforcement programs that seek success by "imposing unsustainable costs" on enemies and criminals, as the U.S. Department of Defense Quadrennial Defense Review suggests. It is about sharing dreams, heroes, and hopes that are more enticing and empowering than any moral lessons or material offerings (although jobs that relieve the terrible boredom and inactivity of immigrant youth in Europe, and with underemployed throughout much of the Muslim world, can help offset the alluring stimulation of playing at war).

How you change youth culture is a difficult and fickle affair. 
Role models or small changes often have big effects on attitudes and fashions (gangster culture, skateboarding, post-Madonna belly-button exposure, Hush Puppies fad). Take the new comic book series of 99 Muslim superheroes, modeled on Marvel comics, which is rapidly catching the imagination of legions of Muslim youth in Southeast Asia and now the Middle East. The first issue of The Ninety-Nine (published in Arabic and English editions beginning in 2006) weaves together heroic slam-bang action in the "fight for peace" with clear messages "to provide services ranging from the distribution of food and medicine to impoverished parts of the world" and "to multicultural educational programs and housing initiatives."

It is also important to provide alternate local networks and chat rooms that speak to the inherent idealism, sense of risk and adventure, and need for peer approval that young people everywhere tend toward. It even could be a $21^{\text {st }}$. century version of what the Boy Scouts and high school football teams did for immigrants and potentially troublesome youth as America urbanized a century ago. Ask any cop on the beat: these things work. It has to be done with the input and insight of local communities, however, or it will not work. De-radicalization, like radicalization itself, engages from the bottom up, not from the top down. This, of course, is not how you stop terrorism today, but how you help prevent it tomorrow.

Scott Atran is Presidential Scholar at the John Jay College of Criminal Justice in New York City, Visiting Professor of Psychology and Public Policy at the University of Michigan, and Research Director in Anthropology at the National Center for Scientific Research in Paris.

\section{For a Printable, PDF version of this Issue, Click Here}

Note: Perspectives on Terrorism invites a diversity of opinions to be presented in articles. The views expressed in this article are those of the author and do not necessarily reflect the views of Perspectives on Terrorism or the Terrorism Research Initiative.

Disclaimer, Terms and Conditions

Joomla Templates by JoomlaShack 